Kazimierz SZAŁATA

IF WFCh UKSW Warszawa

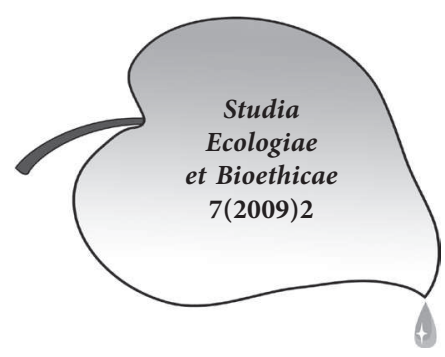

\title{
Problem uporczywej terapii w świetle filozofii człowieka
}

Problemy moralne związane $\mathrm{z}$ koniecznością podejmowania decyzji dotyczących zaprzestania uporczywej terapii w imię chronienia godności osobowej człowieka stanowią z pewnością najtrudniejszą część etyki zawodów medycznych. Zwykle omawiane są one w szerszym kontekście w odniesieniu do eutanazji, zabójstwa, ale też i podmiotowości osoby ludzkiej i jej prawa do godnego umierania. To oczywiście sprawia, że zagadnienie uporczywej terapii pojawia się w wielu kontekstach, które należy przy każdej okazji starannie porządkować. Inaczej dyskusje, nawet te toczone w gronach specjalistów przypominać muszą niekończący się dialog głuchych. Tymczasem wraz z niesłychanie dynamicznym rozwojem medycyny, która wciąż rozszerza swe możliwości terapeutyczne, w społeczeństwach wysoko rozwiniętych, debata dotycząca konieczności zaprzestania uporczywej terapii na ostatnim etapie ludzkiego życia staje się coraz wyraźniej okazją do jednoznacznego żądania możliwości arbitralnego decydowania człowieka o swoim życiu - co oznacza otwarcie furtki do akceptacji, a tym samym powszechnej legalizacji eutanazji, zwanej inaczej śmiercią na życzenie.

Paradoks ten nie może być wyjaśniony na poziomie czysto medycznym. Jeśli traktujemy medycynę jako zespół szczegółowych nauk przyrodniczych, raz po raz odkrywamy potrzebę powrotu do jej filozoficznych korzeni, przede wszystkim zaś do antropologii filozoficznej. Prof. Georges Cottier z Uniwersytetu we Fryburgu uważa, że błędem jest traktowanie etyki, jako czegoś zewnętrznego wobec medycyny, która skierowana jest bezpośrednio na praktykę. Etyka bowiem zawiera się w sposób istotny w medycynie ${ }^{1}$, inaczej medycyna traci coś bardzo ważnego i schodzi do poziomu każdej innej nauki. Dlatego obserwujemy dziś pilną potrzebę wspólnego rozwiązywania interdyscyplinarnych zagadnień bioetycznych, do których należy bez wątpienia problem uporczywej terapii. Nie ma też nic dziwnego

„Il convient de le dès le début, de souligner que la dimension éthique est essentielle à la pratique médicale, elle en est une composante intrinsèque, elle ne vienne pas s'y superposer comme du dehors, alors que celle-ci serait déjà pleinement constituée”. Georges Cottier: „Défis éthiques” Editions Saint AugustinSaint Maurice 1996, s. 157. 
w tym, że raz po raz lekarze stający na co dzień w sytuacji trudnych wyborów $\mathrm{w}$ zakresie stosowania lub zaniechania medycznych działań terapeutycznych i paliatywnych zwracają się o pomoc do etyków, filozofów i teologów.

\section{Medykalizacja ludzkiego życia}

Choroba, proces leczenia, agonia, umieranie nie są tylko psychofizycznymi stanami biologicznego organizmu, ale faktami z życia osobowego człowieka. Nie bez znaczenia jest fakt, że żyjemy w epoce medykalizacji życia ludzkiego. Wszystko, co dzieje się w naszym życiu ma swój medyczny wymiar; rodzimy się w szpitalu, kontrolujemy stan naszego zdrowia, szczepimy się, chorujemy i ostatecznie najczęściej umieramy w szpitalu.

Profesor Jacques Delcourt z Uniwersytetu w Louvain w procesie medykalizacji upatruje jeden z podstawowych czynników kryzysu człowieka, który karmi się iluzją zapewnienia sobie szczęścia farmakologicznymi środkami chemicznymi i sofistyczną aparaturą medyczną ${ }^{2}$. Iluzja ta, zrodzona jeszcze w kręgach pozytywistów pod koniec dziewiętnastego wieku, z jednej strony daje poczucie niemal bezgranicznych możliwości decydowania o własnej kondycji psychofizycznej i o własnej wartości, z drugiej zaś doprowadza do przyjęcia rezygnacji z życia wtedy, gdy ta wizja okazuje się być niemożliwa do zrealizowania. Nic więc dziwnego, że nie potrafimy racjonalnie zachować się przy podejmowaniu trudnych decyzji u kresu żucia, gdy medycyna nie ma już nic do zaproponowania na poziomie terapii, która przerwałaby proces agonii kończący się śmiercią.

Atmosfera totalnej medykalizacji naszego życia nie pozwala nam na rezygnację z działania, jakbyśmy rzeczywiście byli panami życia i śmierci. Kiedy już nic racjonalnego nie możemy zrobić, a sama terapia paliatywna wydaje nam się być po prostu medyczną porażką, zwykła ludzka pycha podpowiada nam, że nawet wtedy nie możemy rezygnować, że możemy jeszcze działać - mianowicie, posłać na dodatkowe, choć $\mathrm{z}$ racjonalnego punktu widzenia niepotrzebne badania i zabiegi, przedłużać w nieskończoność agonię, a jeśli pacjent tego sobie życzy, przyspieszyć śmierć w akcie eutanazji biernej lub czynnej.

Nie potrafimy zatrzymać się, usiąść przy łóżku chorego, którego życie wyraźnie dobiega kresu, akceptując podstawową prawdę, że nawet najlepszy specjalista w dziedzinie medycyny nie jest panem życia i śmierci, ale jest kimś, kto służąc człowiekowi choremu poprzez swoją wiedzę i nabyte umiejętności, może w miarę swych możliwości pomóc mu w potrzebie. Wbrew pozorom u podłoża stosowania niepotrzebnej, uporczywej terapii, jak i akceptacji eutanazji leżeć może ta sama pycha i brak respektu dla człowieka, którego życie dobiega kresu.

2 Jacques Delcourt: "L'home est-il perfectible? Les sciences et les techniques en quête de réponse” w: "Car s'est de l'homme qu'il s'agit” sous la direction de Paul H. Dembinski, Nicolas Buttet, Ernesto Rossi di Montelera, Parole et Silence ed. Desclée de Brouwer, Paris 2007, s. 213 - 214. 
„Karta Pracowników Stużby Zdrowia” posługuje się w odniesieniu do pracy lekarzy wraz z całym personelem medycznym pojęciem „służba życiu”"3. Nikt zatem nie może rozporządzać ludzkim życiem, ale może i powinien mu służyć. Być może to banalne przypominanie podstawowych zasad funkcjonowania medycyny może być uważane, za naiwne, ale dobrze uprawiana medycyna rodzi się nie tylko z wiedzy, ale również z moralnej postawy pracowników służby zdrowia. W naszej hipokratejsko-chrześcijańskiej tradycji ${ }^{4}$ służba człowiekowi choremu wyniesiona została na najwyższy poziom odniesień międzyludzkich stając się realizacją miłosierdzia. Przypominanie tej prawdy ma niesłychanie ważne znaczenie dla głębokiego podjęcia zagadnień moralnych, związanych z opieką medyczną nad człowiekiem u kresu jego ziemskiego, biologicznego życia. Nie można też zapominać, że na poziomie teologicznym, umierający człowiek jest na etapie przejścia do nowego życia w Bogu. ${ }^{5}$

\section{Czym jest uporczywa terapia?}

Odwołując się do klasycznej tradycji arystotelesowskiej, należałoby najpierw pokusić się o precyzyjną definicję uporczywej terapii, a zwłaszcza momentu, w którym terapia ta "de facto" przestaje być terapią, stając się zespołem niepotrzebnych już, uporczywych działań, których winniśmy zaprzestać. Okazuje się, że wcale to nie jest takie proste.

Jeśli pojęcie uporczywej terapii, zdefiniujemy przez samo odniesienie do śmierci, jako nieuchronnego kresu choroby, to w każdym wypadku przerwanie zabiegów terapeutycznych byłoby uzasadnione, gdyż z zasady życie każdego z nas a zwłaszcza człowieka chorego zmierza w sposób naturalny i konieczny do śmierci. Jak znakomicie prezentuje to przywołana już „Karta Pracowników służby zdrowia", w przypadku stosowania uporczywej terapii chodzi jednak nie o przedłużanie życia, ale o przedłużanie agonii, to jest ostatniego etapu kończącego się życia, w którym żadne nasze działanie nie służy już choremu, a może przysparzać mu niepotrzebnych cierpień. ${ }^{6}$ Wspomniany dokument przypomina też,

3 „Karta Pracowników Stużby Zdrowia”, Papieska Rada do spraw Duszpasterstwa Służby Zdrowia, Watykan (polska edycja: Międzyuczelniane Konwersatorium Etyki „Medycyna na miarę człowieka") 1995 , s. 9.

4 Więcej na temat tradycji hipokratejsko-chrześcijańskiej medycyny w: Kazimierz Szałata „Hippocrate, ou est-il aujourd'hui?” Les actes Colloque Internationale „Ethique, Finance et Responsabilité" au Château de Bossey, à Genève le 3 - 4 octobre 2008.

5 Bardzo ciekawe uwagi na temat odniesienia lekarza do wiary pacjenta dotyczącej powołania do życia wiecznego (zwłaszcza w sytuacji zagrożenia śmiercią) znaleźć można w artykule prof. Krystyny Osińskiej. Patrz: K. Osińska: „Lekarz a życie religijne chorych” w: „Refleksje nad etyka lekarskq" praca zbiorowa pod red. K. Osińskiej, Warszawa 1992, s. 165 - 172.

6 Tamże, s. 100. 
że umieranie jest niczym innym, jak jednym z etapów życia. Umiera bowiem nie trup, ale żywy człowiek zamykający za sobą własną historię̨

Uwaga ta pozwala nam lepiej zrozumieć na czym właściwie polega śmierć, jako wypełnienie osobowego życia człowieka. Ponadto patrząc na śmierć, jako na ostatni etap życia możemy lepiej zrozumieć, że życie jest wartością niezależną od jego jakości i warunków, w których się spełnia. Człowiek umierający, bez względu na swój status społeczny, wykształcenie, zdolności, jest człowiekiem żyjącym, przeżywającym wypełnianie się jego życia osobowego, wypełnianiem się jego odniesień do najbliższych, a także do tych, którzy sprawują nad nim opiekę. Nawet wtedy, gdy z punktu czysto medycznego, nie możemy już pomóc pacjentowi stojącemu wobec nieuchronnie zbliżającej się śmierci, mamy jeszcze wiele do zrobienia. Paradoksalnie rzecz biorąc, oprócz stałej życzliwej obecności przy umierającym, możemy mu ulżyć stosując środki znieczulające, możemy też zaprzestając wyniszczającej i niczemu nie służącej uporczywej terapii, pozwolić mu godnie odejść z tego świata. W podobnym duchu Konferencja Episkopatu Francji w dokumencie z 1991 roku „Respecter l'homme proche de sa mort” zwraca uwagę na to, iż zaprzestanie stosowania środków podtrzymujących życie jest wtedy usprawiedliwione, gdy celem podejmującego decyzję lekarza nie jest sprowadzenie śmierci, ale zatrzymanie czysto technicznego przesuwania momentu śmierci, które niczego nie wnosi, powodując tylko cierpienie fizyczne umierającego człowieka i jego najbliższych ${ }^{8}$.

Prof. Suzanne Raimex z Wydziału Medycyny na Uniwersytecie Paryż XII w Creteil przywołuje pierwszą ważną deklarację Piusa XII z 1957 roku dotyczącą reanimacji. Otóż w owym dokumencie papieskim pojawia się odróżnienie między zwyczajnymi i nadzwyczajnymi środkami terapeutycznymi. Zasada ta jest słuszna i do dziś stosowana przy próbach odróżniania reanimacji, uporczywej terapii czy eutanazji. Jednak praktyczne zastosowanie tej zasady nie jest już rzeczą łatwą. Coś, co było w 1957 roku środkiem nadzwyczajnym, dziś może być zupełnie zwyczajną, powszechnie stosowaną terapią ${ }^{9}$. Podobnie jest $\mathrm{z}$ drugą wymienioną w przywołanym dokumencie zasadą proporcjonalności stosowania środków do możliwych do uzyskania efektów. Zasada ta również nie jest prostym algorytmem gotowym do aplikacji w konkretnych przypadkach i nie może być stosowana w sposób mechaniczny. Spodziewane bowiem rezultaty zawsze są hipotetyczne. Nawet uznanie procesu ostatecznej degradacji funkcji życiowych jako nieodwracalnego procesu nie jest jednoznaczną zasadą. Proces wyniszcza-

\footnotetext{
O. Mieczysław Albert Krąpiec używa trafnego pojęcia „spełniania się czasu człowieka” Por. M. A. Kerąpiec: „Człowiek w perspektywie śmierci” w: „O Bogu i człowieku. Problemy filozoficz$n e$ " praca zbiorowa pod red. Bpa Bohdana Bejze, Warszawa 1968, s. 136.

Documentation Catholique, octobre 1991, s. $904-908$.

9 Suzanne Rameix: „Fondements philosophiques de l'éthique médicale”, Collection Sciences Humaines en Médecine, Ed. Ellipses, Paris 1996, s. 31.
} 
nia organizmu w rdzeniowych zanikach mięśni, w przewlekłej obturacyjnej chorobie płuc, jest nieodwracalny, choć trwa w czasie, którego nie wolno zabierać choremu.

\section{Osobowy charakter ludzkiego życia}

By lepiej zrozumieć tajemnice kończącego się życia, trzeba przede wszystkim spojrzeć głębiej na pełny wymiar osoby ludzkiej ${ }^{10}$, której życie nie kończy się na sali reanimacyjnej. Reanimacja, tak jak inne działania terapeutyczne, jest próbą przywrócenia zaburzonych życiowych funkcji organizmu zniszczonego przez chorobę lub uszkodzenia spowodowane doznanymi urazami. Jest zespołem działań wspierających niewydolny organizm, który sam nie jest w stanie utrzymać swoich życiowych funkcji. Celem tych działań jest zawsze ochrona życia człowieka, gdyż zaburzone funkcje ciała prowadzić mogą $\mathrm{w}$ drastycznych przypadkach do śmierci.

Zaprzestanie jakiejkolwiek terapii nie może być nigdy i pod żadnym pozorem aktywnym pozbawieniem człowieka w imię jakichkolwiek innych racji, jak tylko wtedy, gdy stosowana terapia utraciła swój sens wobec ostatecznej degradacji funkcji umierającego organizmu ludzkiego. Jedyny warunek, w którym odstąpienie od działań reanimacyjnych i terapeutycznych staje się racjonalną decyzją, spełniony jest wówczas, gdy wyczerpały się możliwości przywrócenia owych zniszczonych funkcji życiowych.

By przeanalizować warunki podejmowania trudnych decyzji dotyczących zaprzestania uporczywej terapii warto postawić kilka ważnych pytań.

- Kiedy, w jakich warunkach i kto może podjąć słuszną decyzję o zaprzestaniu działań, które nie mają już charakteru terapeutycznego?

- W oparciu o jakie kryteria winna być podjęta taka decyzja?

- Czy ma tu jakieś znaczenie wcześniej wyrażana wola pacjenta, wola najbliższej rodziny?

Takich ważnych pytań jest oczywiście znacznie więcej. Wskazują one wyraźnie, że problem nie wyczerpuje się na poziomie czysto technicznym, medycznym, ale sięga do podstawowych zagadnień antropologicznych, egzystencjalnych, religijnych, sięga do prawdy o człowieku, o jego osobowym życiu i przeznacze$n^{11}{ }^{11}$. Nie czas, by szukać teraz odpowiedzi na wszystkie rodzące się tu pytania.

10 Warunkiem dobrej praktyki medycznej jest umiejętność spojrzenia na pacjenta, który przychodzi do gabinetu lekarskiego nie ze źle funkcjonująca wątrobą, bólem, który trzeba usunąć, ale przychodzi jako człowiek cierpiący z cała własną historią, lękami i nadziejami, by spotykając podczas wizyty spotkać kompetentnego człowieka, który odpowie na jego potrzeby. Paoul Tournier: „Médecine de la personne” Sixième Édition, Delachaux \& Niestlé S. A. Neuchatel Paris 1942, s. 3.

11 Przywoływana już tutaj praca pani profesor Suzanne Rameixw sposób syntetyczny ukazuje paradoks rozwoju medycyny na przestrzeni wieków. Otóż przez całe stulecia medycyna towarzy- 
Chciałbym tylko zwrócić uwagę na kilka ważnych elementów, jakie pojawiają się w dyskusjach wokół omawianych zagadnień.

Problem uporczywej terapii bardzo często wyjaśniamy odwołując się do pojęcia godności osoby ludzkiej. Trzeba powiedzieć, że jest to słuszny punkt wyjścia do rozważań nad człowiekiem, zwłaszcza u kresu jego życia. Trudno jednak znaleźć dziś postawy do pełnego zrozumienia godności, jeśli zdajemy sobie sprawę $\mathrm{z}$ tego, że pojęcie to dawno już oderwano od swych teologicznych korzeni, co sprawiło, że straciło ono swe podstawowe znaczenie.

Nie można zrozumieć „dignité” bez pojęcia „divinité”. Inaczej wyraził to papież Jan Paweł II mówiąc, że nie można zrozumieć człowieka bez Chrystusa. Nie można do końca zrozumieć godności osoby ludzkiej bez prawdy o wcieleniu i odkupieniu człowieka. Owszem, można dochodzić do zrozumienia pojęcia godności osobowej człowieka biorąc za punkt wyjścia analizę skutków jego rozumnej natury, która czyni go bytem świadomym, wolnym - inaczej mówiąc - osobowym. Ale, by to zrobić, potrzebna jest zapomniana dziś klasyczna metafizyka człowieka $^{12}$.

\section{Od teorii do praktyki}

Zaprzestanie uporczywej terapii przeciwstawiamy eutanazji wtedy, gdy mamy do czynienia z wyraźnym życzeniem pacjenta lub przeciwstawiamy zabójstwu, gdy mamy do czynienia z sytuacją, w której pacjent nie wyrażał swej woli dotyczącej ostatniego etapu życia. To zestawienie pojęć uwyraźnia dramatyczność sytuacji, w której postawiony jest personel medyczny, mający podjąć decyzję o zaprzestaniu uporczywej terapii. Nawet wtedy, gdy w etyce ustalimy dosyć precyzyjne normy postępowania, gdy określimy, iż decyzja o zaprzestaniu stosowania nadzwyczajnych środków wobec człowieka zbliżającego się nieuchronnie do końca życia jest moralnie usprawiedliwiona, nie unikniemy kłopotów z określe-

szyła człowiekowi w jego cierpieniu, wspierała go i umacniała w trudnych chwilach, w czasie choroby i w umieraniu, ale niewiele miała do zaproponowania wobec groźnych chorób, które dziesiątkowały ludzi. Ale od XIX wieku, a zwłaszcza od wieku XX wraz z medycyną eksperymentalną, pojawieniem się szczepionek, antybiotyków, możliwości genetyki dokonała się całkowita rewolucja. Wiedza i technika stały się skutecznym narzędziem zwalczania chorób, ale zarazem dokonała się rewolucja w relacji lekarz-pacjent. Chory stał się przedmiotem działań terapeutycznych, przestał być traktowany jako człowiek potrzebujący pomocy. Por. Suzanne Rameix:"Fondements philosophiques de l'éthique médicale", s. 13.

12 We wrześniu 2008 brałem udział w sesji organizowanej przez Stowarzyszenie Justitia et Pax w Instytucie Katolickim w Paryżu, gdzie powtarzano definicję Émile Littrégo, w myśl której godność polega na tym, że widzi się w drugim człowieku to, co chcielibyśmy, by dostrzegano i respektowano w nas samych. Takie zredukowanie pojęcia godności do swoistego rodzaju zespołu subiektywnych życzeń nie wystarczy do obiektywnego uzasadnienia racjonalnych działań wobec człowieka, zwłaszcza u kresu życia. 
niem tego momentu w procesie pogarszania się stanu pacjenta, w którym możemy z całą pewnością powiedzieć „Już”.

Pozostaje też kwestia, kto ma taką decyzję podejmować. Najczęściej dziś szuka się ucieczki od jednoosobowego decydowania o przerwaniu terapii podtrzymującej życie poprzez odwołanie się do komisji etycznej ${ }^{13}$. Jest wiele racji, dla których taka procedura jest zazwyczaj akceptowana. Nie jest to jednak ani idealne, ani zadowalające rozwiązanie.

Komisje etyczne, jakie znamy, czy to w Polsce, czy na świecie, nie są komisjami etycznymi w ścisłym tego słowa znaczeniu, w związku z tym, wbrew oczekiwaniom społecznym, nie są w stanie wypracować precyzyjnych ocen i odpowiedzi na trudne pytania moralne z poziomu etyki, jako nauki. Bardzo często w składzie takich komisji, które niemal zawsze mają charakter interdyscyplinarny, w ogóle nie ma etyka, a jeśli nawet jest, to i tak rezultatem pracy komisji jest wspólnie ustalony konsensus, niekoniecznie zgodny z zasadami etyki. Zatem komitety etyczne pełnią ważna rolę, ale jest to rola opiniotwórcza. Etyka zaś nie jest zespołem opinii, jest naukową refleksją nad ludzkim działaniem opartą na prawdzie o człowieku, jako podmiocie tegoż działania ${ }^{14}$.

Pod koniec ubiegłego roku, podczas sesji naukowej dotyczącej trudnych problemów moralnych współczesnego świata znalazłem się w zespole tematycznym dotyczącym szeroko rozumianej bioetyki, obok przewodniczącej komisji etycznej jednej z klinik w Lozannie. Otóż dowiedziałem się ze zdziwieniem, że w tej szwajcarskiej klinice w podejmowaniu decyzji o zaprzestaniu uporczywej terapii nie uczestniczy lekarz prowadzący ani rodzina. Rozumiem, że chodzi o uniknięcie emocjonalnych odniesień. Człowiek jednak jest osobą nie przedmiotem i nie da się uciec od subiektywizmu, byleby tylko postępować racjonalnie. Inaczej grozi nam bezduszność. Najbardziej jednak zdumiało mnie wyłączenie lekarza prowadzącego z możliwości podejmowania decyzji o zaprzestaniu działań terapeutycznych. Któż bowiem, jeśli nie lekarz, który na co dzień zajmuje się chorym ma więcej do powiedzenia w sprawie określenia momentu i warunków zaprzestania uporczywej terapii? Nie oznacza to jednak, iż chciałbym całkowitego wykluczenia udziału innych osób, które mogłyby pomóc lekarzowi w dokonaniu trafnej oceny stanu pacjenta, pozostając w życzliwym kontakcie z rodziną chorego.

W odniesieniach lekarz - pacjent - relacja do osób najbliższych chorego jest nieunikniona i pożądana - choć bardzo często bywa ona trudna w realizacji. Rodzina, przyjaciele siłą rzeczy uczestniczą w procesie leczenia na każdym jego

13 Zdarza się też, że podjęciem takiej decyzji obarcza się sąd, jak to zdarzyło się niedawno we Włoszech w przypadku odłączenia od sztucznego karmienia pozostającej w śpiączce Eluany, co jest z merytorycznego punktu widzenia zwykłym nieporozumieniem.

14 „Etyka, jest to nauka filozoficzna, która ustala moralne podstawy i reguły ludzkiego działania przy pomocy wrodzonych człowiekowi zdolności poznawczych”. Tadeusz ŚLIPKO: „Etyka ogólna" WAM Kraków 1974, s. 16. 
etapie, otaczając go troską, życzliwością przejawiającą się również w tym, że z zaufaniem powierzają zdrowie i życie chorego, tym, którzy zgodnie ze swoimi kompetencjami mogą je chronić i ratować. Oczywiście możliwe jest to przy zachowaniu granic kompetencji każdego uczestnika procesu leczenia, a kiedy już wyczerpią się wszystkie możliwości terapeutyczne, również i umierania pacjenta.

Żadna komisja nie może zdjąć odpowiedzialności lekarza prowadzącego za los pacjenta. To on najlepiej zna przebieg choroby i w oparciu o ewentualne konsultacje z innymi specjalistami jest $\mathrm{w}$ stanie określić kiedy terapia staje się zwykłą manipulacją. Co to znaczy? Terapia jest działaniem lub zespołem działań diagnostycznych czy terapeutycznych, których celem jest dobro pacjenta. Manipulacja jest działaniem lub zespołem działań, których cel jest inny, niż dobro pacjenta, choć czasem wydawać się może szlachetny; lęk przed pomyłką, pokazanie rodzinie, że bardzo się staramy, robimy więcej, niż to niezbędne itd.

Mówię to nie jako teoretyk, ale jako ktoś, kto niemal dokładnie sześć lat temu stanął przy lekarzach ratujących życie mojej jedenastoletniej córeczki Ani. W poczuciu bezsilności, ale z zaufaniem asystowałem na oddziale intensywnej terapii przy ul. Niekłańskiej w Warszawie wysiłkom zespołu reanimacyjnego. W pewnym momencie lekarka, znając mnie z wcześniejszych wystąpień w Akademii Medycznej, zwróciła się do mnie z pytaniem, czy zaprzestać działań, gdyż one stały się nieskuteczne. Pamiętam, że spokojnie odpowiedziałem, „to Pani wie, jak racjonalnie postępować”. To prawda, że chciałem poruszyć niebo i ziemię, żeby uratować córeczkę, ale wiedziałem, że jeśli już nie ma możliwości przywrócenia utraconych funkcji życiowych, trzeba jej dać spokojnie odejść.

Dziś nie mam poczucia, że wydałem wyrok na własne dziecko. I chcę tu podziękować wszystkim, z którymi przegadałem w Konwersatorium „Medycyna na miarę człowieka" w warszawskiej Akademii Medycznej wiele godzin o dramatycznych momentach związanych z podejmowaniem trudnych decyzji medycznych. Jednym z uczestników moich zajęć bywał rektor Akademii Medycznej, pan profesor Tołłoczko, od którego wiele się nauczyłem, między innymi tego, że rezygnacji z uporczywej terapii nie możemy traktować jako naszej osobistej i zawodowej porażki ${ }^{15}$. To przy łóżku chorego i to w jego terminalnym stanie uczymy się pokory, która jest warunkiem mądrości. Zaprzestanie uporczywej terapii, jest wyrazem pokory i mądrości. Pokora i mądrość wsparte rzetelną wiedzą medyczną są prawdziwymi wyznacznikami granic terapii medycznych.

15 Prof. Tadeusz Brzeziński pisze: „Przekonanie, że lekarz jest po to, by uzdrawiać i ratować życie tak głęboko wryło się w mentalność pokoleń lekarzy, że każdy przypadek, w którym jest to niemożliwe, do dnia dzisiejszego traktują wstydliwie i nawet wobec siebie odczuwają wstyd i gorycz klęski.” por. Tadeusz BRZEZIŃskI: „Tradycyjne zasady deontologii lekarskiej” w: „Etyka i deontologia lekarska” pr. zbiorowa pod redakcją Tadeusza Kilelanowskiego, wyd. II zmienione i rozszerzone, Warszawa 1985, s. 69. 


\section{Podsumowanie}

Trudności związane z rozwiązywaniem problemów etycznych w medycynie biorą się w głównej mierze z kryzysu antropologii, czyli filozoficznej torii człowieka. W dokumentach legislacyjnych na poziomie krajowym i międzynarodowym unika się filozoficznego pojęcia osoby ludzkiej uznając je niesłusznie za zbyt mocno związane z teologicznymi ujęciami człowieka. „Osobę ludzką" najczęściej zastępuje się bliżej nieokreślonym pojęciem jednostki ludzkiej. Jeśli tak jest, trudno dziś budować refleksję moralną na poziomie etyki, która w tej sytuacji zastępowana jest przez zwykłe opinie pojawiające się i utrwalane w kulturze. Dzięki temu $\mathrm{w}$ powszechnym myśleniu o zagadnieniach z poziomu bioetyki dominują ujęcia subiektywistyczne odwołujące się do emocji związanych z określonymi, trudnymi stanami ludzi chorych. To te właśnie emocjonalne ujęcia prezentujące wartość człowieka zrelatywizowaną do jakości jego życia są w głównej mierze źródłem usprawiedliwiania pokusy eutanazji.

Trzeba zauważyć też, że wszelkie próby ustalenia granicy życia w naukach eksperymentalnych, opartych na empirycznej obserwacji procesów zachodzących w organizmie chorego, są skazane na niepowodzenie i muszą siłą rzeczy prowadzić do arbitralnych rozwiązan ${ }^{16}$. W procesie, który jest nieustannym przepływem, nieustanną zmianą, nie da się jednoznacznie, wyznaczyć takiej granicy. Nie znaczy to jednak, że nie można zdefiniować faktu śmierci. Można, ale tylko w filozofii człowieka, która jest pomijana w toczonych tu i ówdzie dyskusjach. Znaczenie antropologii filozoficznej z poziomu arystotelesowskiej realistycznej metafizyki bytu opisał o. Mieczysław Albert Krąpiec w swojej książce „Ja człowiek” ustalając najpierw podstawowe zasady metodologiczne, które pozwoliłyby ująć człowieka w całej swej materialno - duchowej złożoności. Oto bowiem z analizy działań człowieka wynika, że jest on bytem nie tylko fizycznym, zajmującym miejsce w czasie i przestrzeni, że jest bytem biologicznym, odżywiającym się i rozwijającym się w czasie, ale również jest to byt rozumny obdarzony wolą pozwalającą na realizowanie się w osobowych aktach miłości. Takie całościowe ujęcie człowieka pozwala na głębsze spojrzenie na zagadnienie ludzkiego cierpienia i śmierci ${ }^{17}$. Życie człowieka przekracza poziom biologiczny. Jest życiem osobowym. Również śmierć jest faktem z osobowego życia człowieka. Śmierć następuje wówczas, gdy dusza pozostająca aktem w stosunku do możności - w postaci materialnego ciała

16 Obrazuje to doskonale tocząca się wciąż dyskusja wokół definicji śmierci w kontekście rozwoju transplantologii. Por. Tadeusz Biesaga SDB: „Kontrowersje wokół nowej definicji śmierci" Medycyna Praktyczna on line" http://www.mp.pl/artykuly/index.php?aid=27742\&_ $\mathrm{tc}=\mathrm{A} 665 \mathrm{~B} 2596 \mathrm{C} 434 \mathrm{C} 939 \mathrm{CB} 8 \mathrm{~A} 2292 \mathrm{D} 5 \mathrm{E} 2880$

17 „Jeśli więc dusza jest - używając arystotelesowskiego języka - formą ciała, albo mówiąc jaśniej, jest jednym aktem bytu człowieka, znaczy to, że ona jest nie tylko racją istnienia - życia - człowieka, ale także organizuje nieustannie materię do bycia materią ludzką - ludzkim ciałem”. Mieczysław Albert Krąpiec: „Ja człowiek” Lublin 1991, s 440. 
przestaje aktualizować ciało. Przestaje być zasadą organizującą materię w żywym ciele. Wtedy materia pozostaje nadal na swoim miejscu, ale nie jest już jednością w obrębie ciała, ale zespołem rozpadających się zespołów komórek.

Jeśli bowiem nie potrafimy zdefiniować życia, a tym samym śmierci, nie jesteśmy w stanie porozumieć się w najważniejszych kwestiach ludzkiego zdrowia i życia. Zatem głównym wnioskiem w debacie dotyczącej kwestii uporczywej terapii, jest konieczność odwołania się do klasycznej filozofii człowieka, konieczność spojrzenia na problem choroby, cierpienia i śmierci poprzez pryzmat życia osobowego człowieka.

\title{
The problem of persistent therapy in philosophical anthropology
}

\begin{abstract}
SUMMARY
The problem of medical futility, which combines the issues of euthanasia, is one of the most difficult matter of medical ethics. The theraphy becomes futile when a patient is in an agonizing state and none of the extraordinary actions can restore the life processes, which are coming to the end. The documents of Catholic Church state that actions which do not serve human life any more should be stopped so that let a man in agony die with dignity. However, under any conditions it is allowed to cause death of a man in active or passive way. Euthanasia is not only against the medical ethos but also the content of the medicine which serves the human life. The author of the article defines the conception of medical futility at the level of anthropological philosophy and notices that in practice the designation of the moment, when we deal with the medical futility, belongs to the doctors who depends on his empiric knowledge and wisdom.
\end{abstract}

